\title{
Sistem Informasi Peminjaman Laboratorium pada Cross-Platform dengan Metode Prototyping (Studi Kasus: Politeknik Caltex Riau)
}

\author{
Leony Veronica Wijaya ${ }^{1 *}$, Shumaya Resty Ramadhani ${ }^{2 *}$ \\ * Teknik Informatika, Politeknik Caltex Riau \\ leony16ti@mahasiswa.pcr.ac.id ${ }^{1}$, shumaya@pcr.ac.id ${ }^{2}$
}

\begin{tabular}{l}
\hline \hline Article Info \\
\hline Article history: \\
Received 2020-01-13 \\
Revised 2020-02-19 \\
Accepted 2020-04-01
\end{tabular}

\section{Keyword:}

BSTI,

React Native,

Laravel,

Cross-Platform,

Firebase Authentication, $M y S Q L$.

\begin{abstract}
The Laboratory information system is one of the information systems that was built by the BSTI of Polytechnic Caltex Riau to provide information about laboratory lending. This system is also being intended to the person who is in charge of approving laboratory lending such as the head of the laboratory, and laboratory assistant in case of monitoring some of the laboratories that are lent. However, the features provided by this information system are not enough to support the process of laboratory lending. Therefore, a mobile application with the quality of CrossPlatform was built, in other words, it can be used on iOS and Android platforms. One of the technologies that can be used to build a cross-platform application is the React Native. This application was built with a prototype method that is used to get more perspective points from users with interviews and can simplify the development of this application to be effective. This application was developed with Laravel, Firebase Authentication, and MySQL. Because there are several problems with the old system, an application that offers several solutions consists of avasisten instruktur laboratoriumbility in the lending laboratory, receiving legal paper of laboratory lending, and receiving notification were developed in this study. The main feature provided in this application is the evidence letter of laboratory lending that doesn't have to be printed so that can reduce paper usage. As a result, $94.1 \%$ of respondents stated that this application's features can run well and make it easy for college students to propose laboratory lending.
\end{abstract}

This is an open access article under the $\mathrm{CC}-\mathrm{BY}-\mathrm{SA}$ license

\section{Pendahuluan}

Sistem informasi merupakan sebuah kombinasi antara teknologi informasi dan aktivitas dari pelaku yang menggunakannya untuk mendukung operasi dan manajemen [1]. Pada aktifitas laboratorium komputer perlu adanya pengelolaan terkait peminjaman ruang. Sistem peminjaman merupakan salah satu sistem yang memiliki peranan penting dalam kegiatan-kegiatan yang memerlukan pengelolaan laboratorium sebagai bagian pendukung suatu kegiatan terkait dalam segi akademik maupun non-akademik di Politeknik Caltex Riau. Sistem peminjaman digunakan untuk menunjang aktifitas peminjaman laboratorium yang dilakukan oleh pengguna (mahasiswa). Untuk memberikan informasi ketersediaan laboratorium yang dapat dipinjam, maka perlu dilakukan pengembangan sistem yang mampu menyediakan dan menampilkan daftar informasi status peminjaman laboratorium yang sedang dipinjam maupun yang selesai dipinjam. Permasalahan utama dari sistem peminjaman laboratorium saat ini adalah bagaimana antarmuka dan fitur yang ditawarkan pada sistem belum dapat mendukung sepenuhnya kegiatan peminjaman laboratorium oleh mahasiswa.

Aktifitas peminjaman umumnya mahasiswa tetap harus melampirkan formulir peminjaman laboratorium dan membutuhkan tanda tangan kepada pihak yang bersangkutan (dalam hal ini yang bertanggungjawab dalam manajemen laboratorium). Padahal sewaktu-waktu tidak berada ditempat. Akibatnya, aktifitas peminjaman yang dilakukan menjadi tidak begitu efektif baik waktu, tenaga dan biaya. Selain itu tidak semua mahasiswa memiliki pengetahuan tentang alur 
peminjaman. Hal ini menjadi kendala utama bagi mahasiswa maupun pihak yang bertanggungjawab atas laboratorium yang terkait dalam mengajukan peminjaman laboratorium dan pemantauan terhadap pengelolaan peminjaman laboratorium.

Beberapa penelitian yang telah dilakukan diantaranya pembangunan sistem informasi inventaris barang laboratorium berbasis Android di STMIK Tasikmalaya [2] yang mampu memberikan solusi untuk menangani masalah penyajian informasi inventaris barang karena pengolahan data inventaris dapat dilakukan dimana saja dengan perangkat smartphone tiap pegawai serta menampilkan informasi barang kapan saja saat dibutuhkan. Kemudian, penelitian lainnya adalah pembangunan aplikasi pemantauan kegiatan siswa berbasis Mobile menggunakan Framework React Native [3] yang menghasilkan aplikasi pemantauan kegiatan siswa untuk melihat kegiatan siswa setiap harinya dan didukung oleh Framework React Native yang berfungsi untuk memberikan layanan pesan push notification sebagai pemberitahun kepada siswa.

Berdasarkan penelitian yang telah dilakukan sebelumnya, maka peneliti membangun sebuah aplikasi peminjaman laboratorium dengan menggunakan teknologi React Native. Dengan adanya teknologi ini, mahasiswa dapat mengakses aplikasi lewat lewat platform $i O S$ ataupun Android sehingga mahasiswa dapat melakukan peminjaman laboratorium dimana saja dan kapan saja. Selain itu, aplikasi ini memberikan fasilitas kepada mahassiwa yang berupa fitur untuk mengajukan peminjaman laboratorium, melihat daftar peminjaman beserta syarat peminjaman, mendapatkan notifikasi dan menerima bukti peminjaman laboratorium sah berformat .pdf yang diberikan oleh asisten instruktur laboratorium.

\section{Metode Penelitian}

Metode penelitian yang dilakukan pertama kali adalah melakukan penelitian terhadap perancangan sistem yang telah dibangun sebelumnya dengan menganalisa fitur apa saja yang belum ada dan fitur pendukung apa yang dapat ditambahkan kedalam pembangunan aplikasi Mobile yang dibangun oleh peneliti. Untuk pembangunan aplikasi ini sendiri, peneliti menggunakan bahasa pemrograman JavaScript yang didukung oleh Node.js [4].

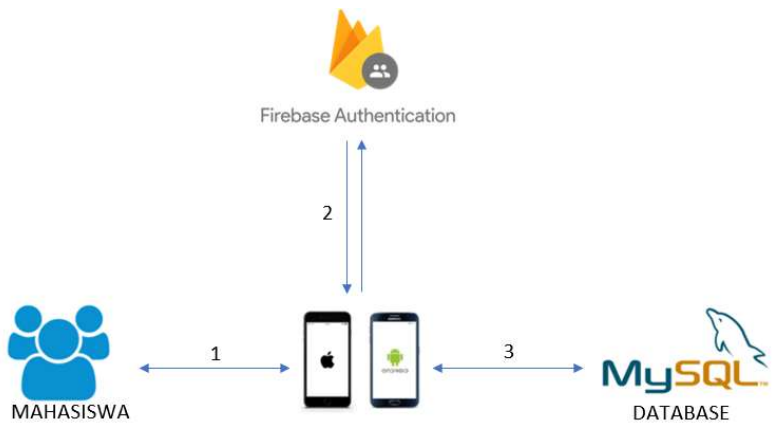

Gambar 1. Arsitektur Sistem
Untuk mengakses aplikasi, mahasiswa yang berperan sebagai pengguna harus melakukan Login kedalam aplikasi dengan menggunakan e-mail dan password yang telah didaftarkan pada Firebase Authentication. Setelah mahasiswa berhasil melakukan login, maka mahasiswa akan diarahkan kehalaman utama dari aplikasi dan apabila pengguna ingin melihat daftar peminjaman atau melakukan peminjaman, maka aplikasi akan melakukan request pada server untuk mengakses data yang tersimpan dalam database MySQL.

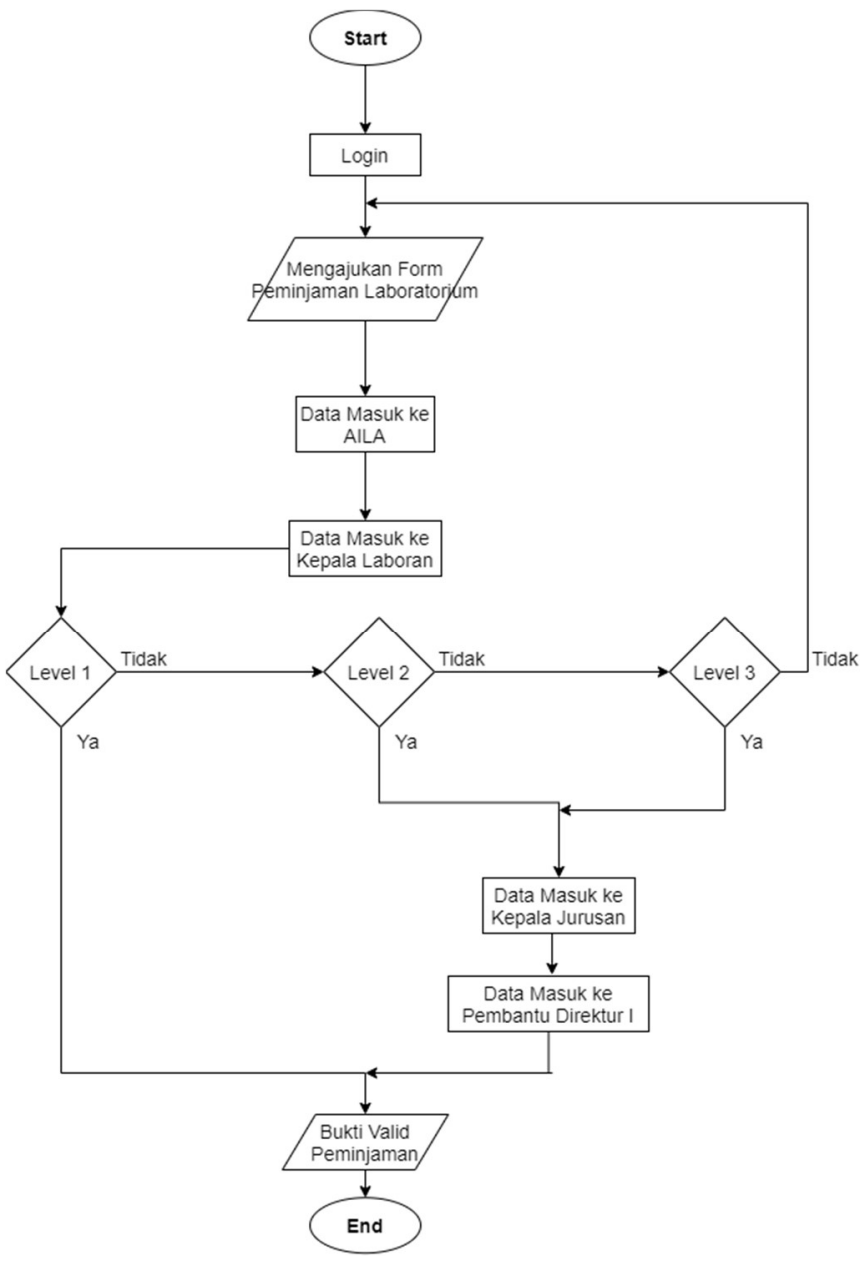

Gambar 2. Flowchart Diagram Peminjaman Laboratorium

Sistem informasi peminjaman lab hanya dapat diakses oleh kepala laboratorium dan asisten instruktur laboratorium yang bersangkutan. Kondisi inilah yang menjadi permasalahan jika terjadi kesalahpahaman dalam peminjaman lab antar mahasiswa. Salah satu solusi yang diajukan adalah menambah akses untuk mahasiswa agar dapat melakukan pengajuan peminjaman lab lewat sistem sehingga asisten instruktur laboratorium, kepala laboratorium, atau kepala jurusan dapat memantau peminjaman secara terstruktur dan jelas. Sehingga diperlukan adanya sistem informasi peminjaman laboratorium berbasis mobile tersebut untuk mempermudah pengajuan peminjaman lab oleh mahasiswa yang ada. Jika pengguna melakukan pengajuan peminjaman 
lab, maka dari kepala laboratorium dan asisten instruktur laboratorium akan memberikan notifikasi pemberitahuan apabila pengajuan yang diajukan diterima atau tidak. Selain itu, kepala jurusan, kepala laboratorium, asisten instruktur laboratorium juga dapat memantau daftar peminjaman laboratorium yang terdaftarkan di sistem.

\section{A. Prototype I}

Metode penelitian yang dilakukan pertama kali adalah melakukan penelitian terhadap perancangan sistem yang telah dibangun sebelumnya dengan menganalisa fitur apa saja yang belum ada dan fitur pendukung apa yang dapat ditambahkan kedalam pembangunan aplikasi Mobile yang dibangun oleh peneliti. Untuk pembangunan aplikasi ini sendiri, peneliti menggunakan bahasa pemrograman JavaScript yang didukung oleh Node.js.

\section{B. Evaluasi Prototype I}

Pada tahap ini, mahasiswa, asisten instruktur laboratorium, dan kepala laboratorium mengevaluasi kebutuhan yang telah dikumpulkan mulai dari pengalaman dalam peminjaman laboratorium, alur atau proses bisnis peminjaman laboratorium dan analisa terhadap sistem informasi laboratorium yang sebelumnya telah dibangun oleh pihak BSTI PCR. Setelah evaluasi, dikeluarkanlah hasil bahwasannya aplikasi ini memang harus dibangun untuk memberikan efisiensi dan efektivitas dalam peminjaman laboratorium, beserta untuk memberikan kemudahan bagi asisten instruktur laboratorium dan kepala laboratorium dalam memantau atau mengontrol kegiatan peminjaman laboratorium tersebut.

\section{Prototype II}

Prototype kedua dilakukan setelah hasil perancangan aplikasi berada pada tahap penyelesaian $80 \%$, dimana dilakukan pengujian terhadap aplikasi yang dibangun. Pengujian pertama dilakukan terhadap mahasiswa pada tanggal 7 Oktober 2019. Pengujian dilakukan secara tatap muka dalam artian menggunakan masing-masing smartphone dari mahasiswa yang ikut serta dalam pengujian. Pengujian aplikasi dilakukan kebeberapa mahasiswa yang memiliki smartphone dengan platform iOS dan Android yang kemudian dimulai dari pendaftaran akun, login akun, mengajukan peminjaman laboratorium dengan formulir yang disediakan, melihat daftar peminjaman, dan mendapatkan notifikasi penolakan atau persetujuan terhadap peminjaman yang diajukan. Aplikasi ini dapat berjalan langsung pada crossplatform sekaligus karena berbasis Cross-Platform [5]. Berdasarkan pengujian yang telah dilakukan, mahasiswa diminta untuk mengisi formulir survei pada Google Form terhadap aplikasi yang telah digunakan atau telah diuji sebelumnya. Didapatkanlah sekitar 94,1\% responden setuju sepenuhnya aplikasi ini lulus uji atau valid. Kemudian, dilakukan pula pengujian terhadap asisten instruktur laboratorium dan kepala laboratorium pada tanggal 9 Oktober
2019 dan diberikan catatan revisi berupa penambahan kolom keterangan untuk peminjaman alat pada laboratorium, dan menambahkan kolom dosen pembina atau pembimbing sebagai yang mengetahui peminjaman dari mahasiswa terkait.

\section{Evaluasi Prototype II}

Pada tahap ini, asisten instruktur laboratorium dan kepala laboratorium melakukan evaluasi terhadap aplikasi yang telah dibangun oleh pengembang. Dimana aplikasi tersebut memiliki fitur notifikasi, peminjaman laboratorium, dan daftar peminjaman laboratorium. Diberikan pula tambahan berupa menambahkan tanggal pengeluaran bukti peminjaman dan nama aplikasi pada halaman bukti peminjaman yang telah digeneralisasi untuk memberikan nilai orisinil terhadap bukti peminjaman laboratorium tersebut.

\section{E. Prototype III}

Prototype kedua dilakukan setelah hasil perancangan aplikasi berada pada tahap penyelesaian 100\%, dimana dilakukan pengujian terhadap aplikasi yang dibangun. Pengujian kedua dilakukan terhadap mahasiswa pada tanggal 14 Oktober 2019 setelah proses pengerjaan sekitar 7 hari menimbang beberapa tambahan yang diberikan oleh pengguna terkait. Berdasarkan hasil pengujian yang dilakukan, didapatkan bahwa aplikasi telah sesuai dan berjalan dengan valid.

\section{F. Evaluasi Prototype III}

Pada tahap ini, asisten instruktur laboratorium dan kepala laboratorium melakukan evaluasi terhadap aplikasi yang telah dibangun oleh pengembang. Dimana aplikasi tersebut memiliki fitur notifikasi, peminjaman laboratorium, dan daftar peminjaman laboratorium. Berdasarkan hasil evaluasi dari asisten instruktur laboratorium dan kepala laboratorium, didapatlah kesimpulan bahwasannya aplikasi ini dapat berjalan dengan valid dan untuk proses bisnis beserta alur yang diterapkan telah sesuai dengan regulasi peminjaman laboratorium yang ada.

\section{ANalisis dan PERANCANGan}

Dalam membangun sistem informasi peminjaman berbasis Mobile ini, peneliti menggunakan metode prototyping yang ditujukan untuk mendapatkan poin penting dari sisi pengguna. Berdasarkan penelitian yang telah dilakukan, peneliti mendapatkan analisa kebutuhan pengguna baik itu mahasiswa maupun pihak yang bertanggungjawab atas laboratorium. Dengan penggunaan metode ini, peneliti mendapatkan hasil rancangan yang tepat dan sesuai dengan permasalahan yang ada serta dapat mempercepat proses pembangunan aplikasi peminjaman laboratorium tersebut yang diverifikasi secara langsung kepada Stakeholders yang bersangkutan. Berikut adalah beberapa rancangan hasil analisa dan evaluasi kebutuhan: 


\section{A. Use Case Diagram}

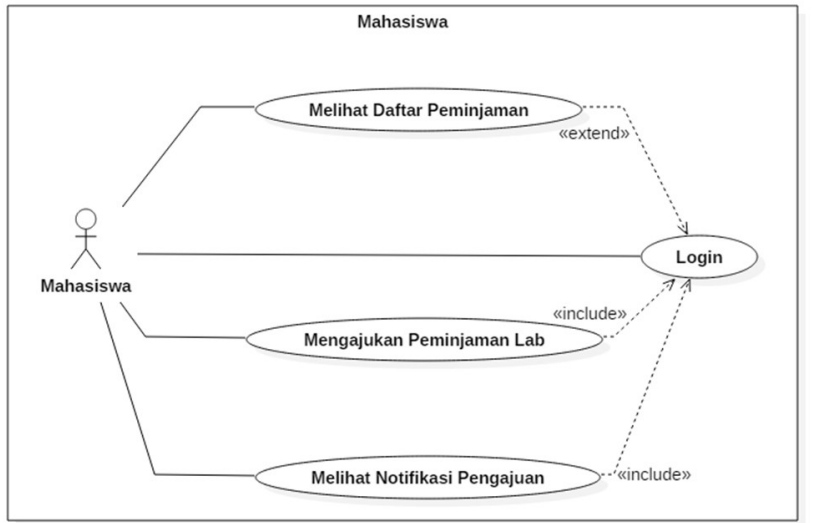

Gambar 3. Use Case Diagram Mahasiswa

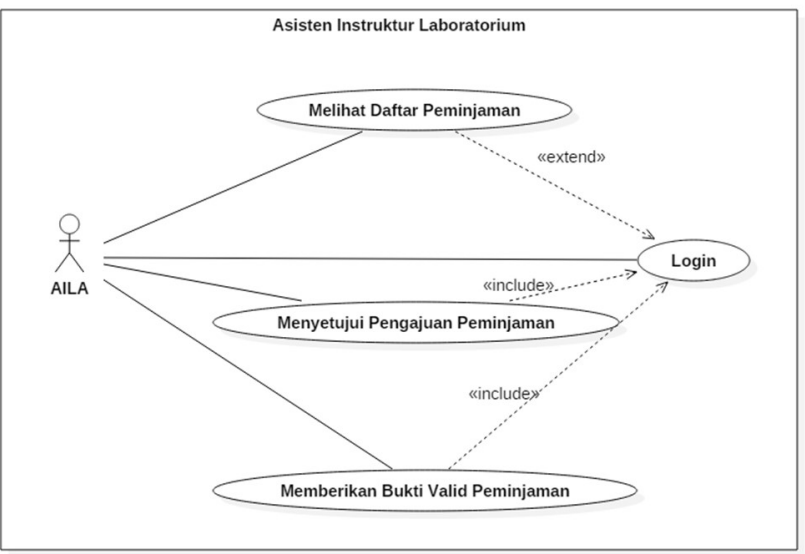

Gambar 4. Use Case Diagram Asisten Instruktur Laboratorium

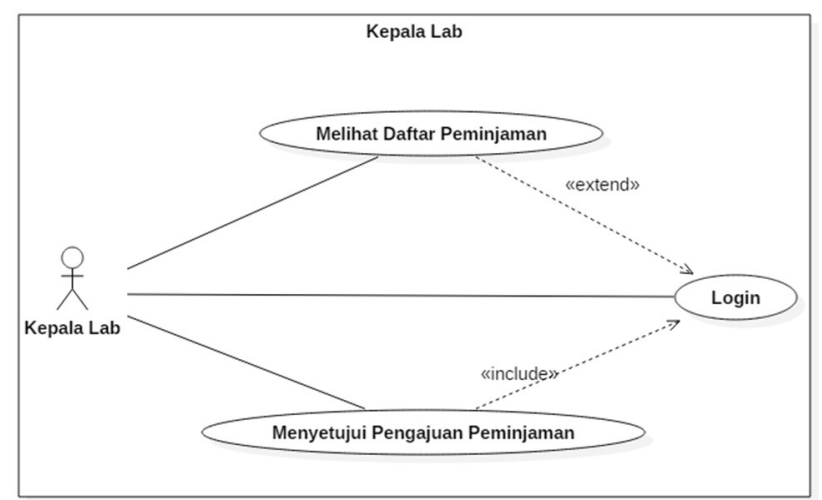

Gambar 5. Use Case Diagram Kepala Laboratorium

Aplikasi ini memberikan fitur dimana mahasiswa dapat melakukan pengajuan peminjaman laboratorium, melihat daftar peminjaman, dan mendapatkan notifikasi peminjaman. Kemudian, asisten instruktur laboratorium dan kepala laboratorium dapat melakukan update untuk peminjaman yang diajukan baik disetujui ataupun ditolak. Selain itu, asisten instruktur laboratorium dan kepala laboratorium juga dapat melakukan operasi delete. Notifikasi juga akan dikirimkan kepada mahasiswa, asisten instruktur laboratorium, dan kepala laboratorium apabila ada peminjaman baru ataupun terdapat persetujuan atau penolakan. Sedangkan untuk asisten instruktur laboratorium dapat dilakukan generalisasi PDF untuk menerbitkan bukti peminjaman setelah semua proses telah dilaksanakan.

\section{B. Sequence Diagram}

Sequence diagram [8] berdasarkan kebutuhan sistem dalam notifikasi peminjaman laboratorium adalah sebagai berikut:

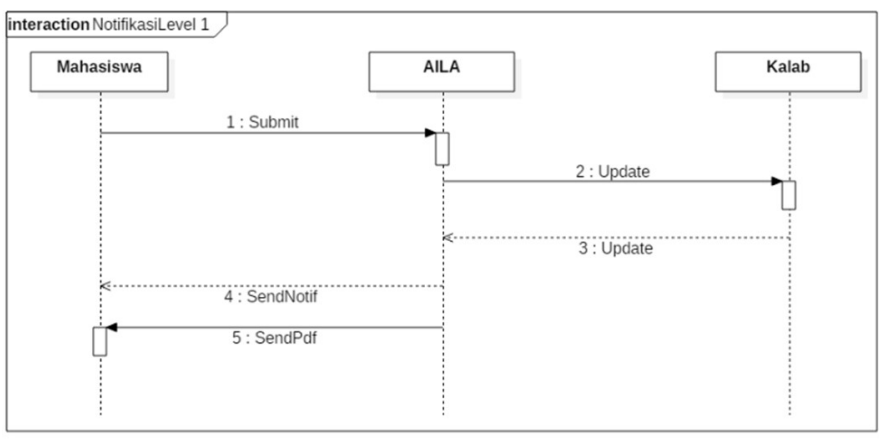

Gambar 6. Sequence Diagram Notifikasi Level 1

Untuk alur dengan peminjaman level 1, tahap pertama kali yang terjadi adalah disaat mahasiswa melakukan peminjaman yang kemudian ketika data tersebut masuk ke database maka notifikasi akan dikirimkan kepada asisten instruktur laboratorium. Setelah disetujui oleh asisten instruktur laboratorium, maka akan dikirimkan notifikasi lagi kepada kepala laboratorium, sehingga setelah semua pihak menyetujui peminjaman yang diajukan, maka notifikasi akan dikirimkan kembali kepada mahassiwa beserta dengan bukti peminjaman yang sah.

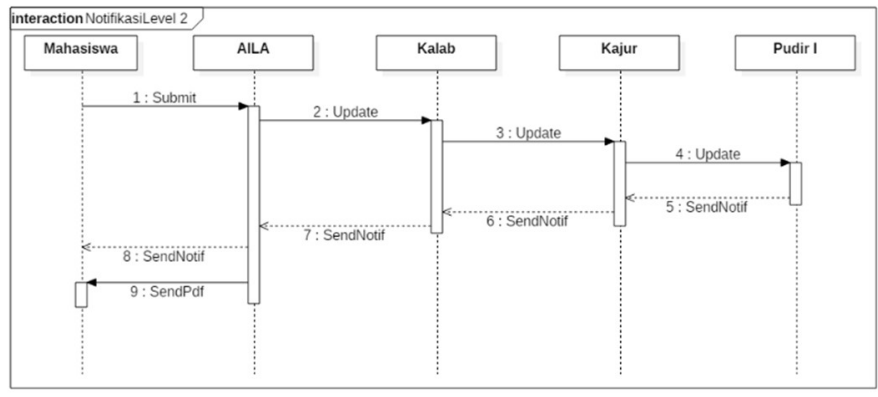

Gambar 7. Sequence Diagram Notifikasi Level 2

Untuk alur dengan peminjaman level 2, setelah mahasiswa mengajukan peminjaman, maka notifikasi baru akan masuk ke aplikasi asisten instruktur laboratorium yang apabila telah disetujui, maka notifikasi akan secara langsung dikirimkan kepihak berikutnya. Pada tahap akhir, apabila pembantu direktur I telah menyetujui peminjaman, maka notifikasi akan kembali dikirim ke mahasiswa beserta dengan butki peminjaman yang sah. 


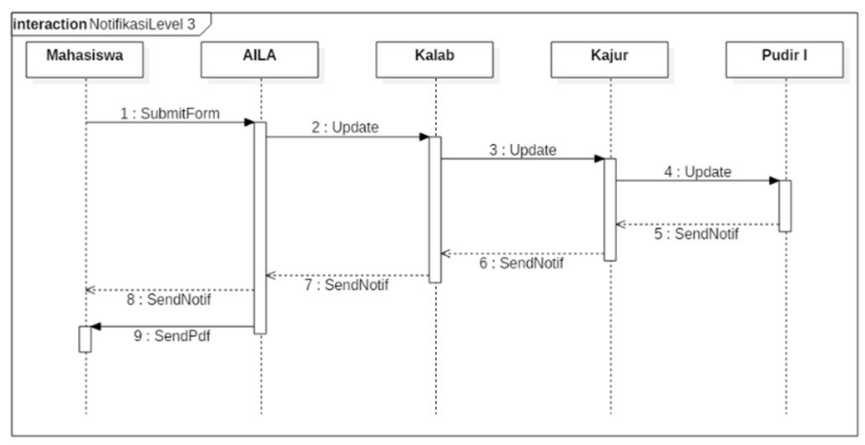

Gambar 8. Sequence Diagram Notifikasi Level 3

Untuk alur dengan peminjaman level 3, setelah mahasiswa mengajukan peminjaman laboratorium untuk hari sabtu dan minggu, maka notifikasi baru akan masuk ke aplikasi asisten instruktur laboratorium yang apabila telah disetujui, maka notifikasi akan secara langsung dikirimkan kepihak berikutnya. Pada tahap akhir, apabila pembantu direktur I telah menyetujui peminjaman, maka notifikasi akan kembali dikirim ke mahasiswa beserta dengan butki peminjaman yang sah. Notifikasi yang dikirimkan kepada masing-masing penanggung jawab menggunakan notifikasi yang disediakan oleh Expo dengan fitur Expo Token [9] [10].

\section{HASIL DAN IMPLEMENTASI}

Implementasi dari Sistem Informasi Peminjaman Laboratorium pada Cross-Platform dengan Metode Prototyping (Studi Kasus: Politeknik Caltex Riau) meliputi dua bagian berupa input dan output dimana input berupa pengajuan peminjaman laboratorium dalam bentuk form yang disediakan aplikasi, dan output yang berupa bukti peminjaman laboratorium yang sah, notifikasi, dan informasi daftar ketersediaan laboratorium baik kuota mahasiswa perlaboratorium pada waktu yang sama, $\log$ terhadap barang atau inventaris laboratorium yang digunakan, daftar jadwal peminjaman laboratorium beserta informasi alur peminjamannya dan jadwal peminjaman laboratorium dengan menggunakan Framework React Native sebagai Front-End yang dapat berjalan dengan baik pada platform iOS dan Android.

\section{A. Hasil Perancangan}

Berikut adalah beberapa halaman yang menjadi poin utama dalam pembangunan Sistem Informasi Peminjaman Laboratorium dengan Metode Prototyping. Pada sisi mahasiswa terdapat halaman untuk melakukan pengajuan peminjaman dan melihat daftar peminjaman. Kemudian untuk asisten instruktur laboratorium terdapat halaman melihat daftar peminjaman yang disertakan button untuk operasi update dan delete. Selain itu, asisten instruktur laboratorium dapat juga menerbitkan bukti peminjaman yang dapat dikirim via email kepada mahasiswa. Sedangkan pada bagian kepala laboratorium terdapat halaman yang akan menampilkan daftar peminjaman laboratorium yang disertakan pula dengan button update dan delete.

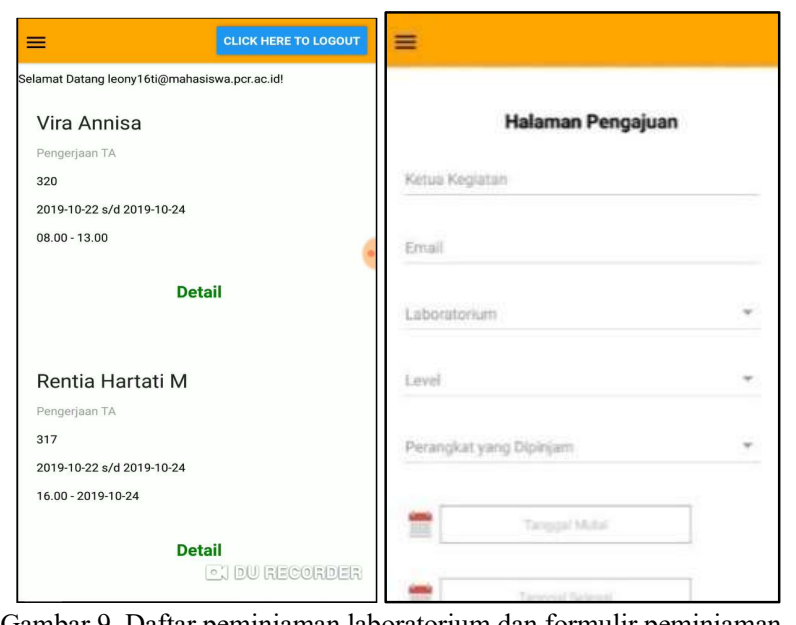

Gambar 9. Daftar peminjaman laboratorium dan formulir peminjaman laboratorium pada sisi Mahasiswa

Pada aplikasi mahasiswa, terdapat fitur daftar peminjaman laboratorium dan formulir peminjaman laboratorium yang ditunjukkan pada Gambar 9. Fitur daftar peminjaman ini membantu mahasiswa untuk mengetahui peminjaman mana saja yang aktif dan berapa kuota yang tersedia apabila ingin melakukan peminjaman pada laboaratorium yang sama.

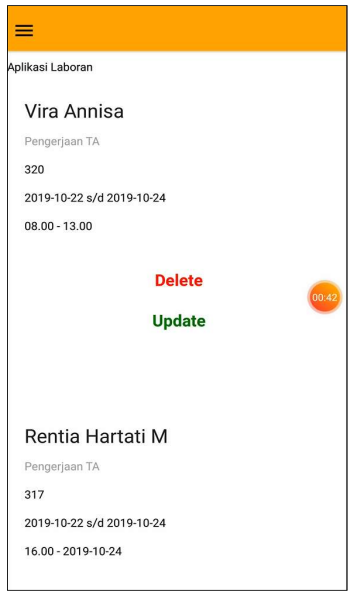

Gambar 10. Daftar peminjaman laboratorium pada sisi Asisten Instruktur Laboratorium dan Kepala laboratorium

Pada aplikasi asisten instruktur laboratorium, terdapat fitur daftar peminjaman laboratorium yang aktif seperti pada Gambar 10 yang dilengkapi dengan fungsi delete dan update terhadap peminjaman yang aktif dan yang akan selesai.
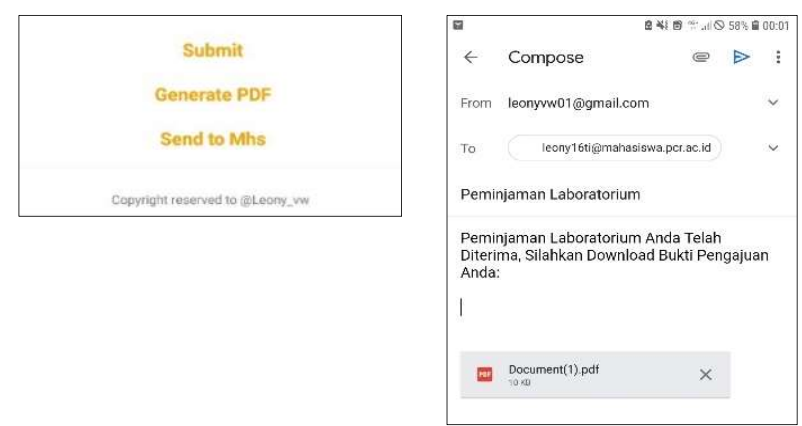


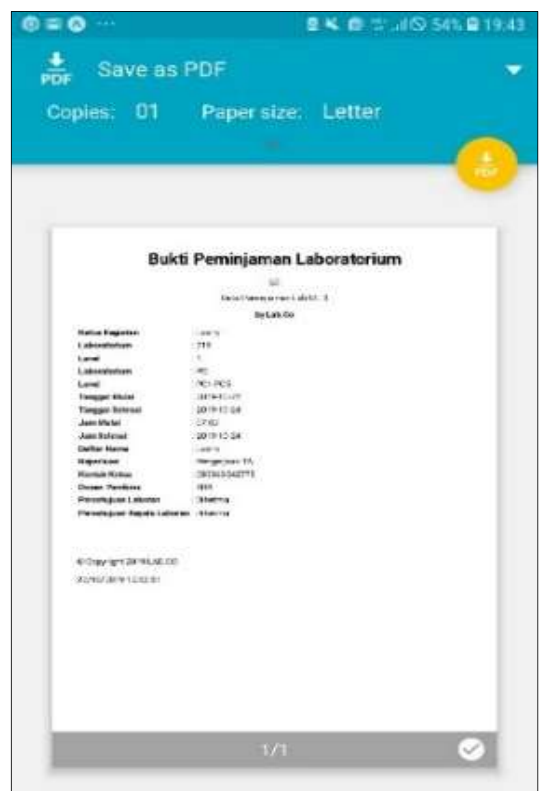

Gambar 11. Fitur update, generate $P D F$, dan pengiriman bukti peminjaman kepada Mahasiswa pada sisi Asisten Instruktur Laboratorium

Selain itu, terdapat pula fitur untuk generalisasi bukti peminjaman kedalam format . $p d f$ yang kemudian dapat dikirimkan kepada mahasiswa lewat e-mail dengan menggunakan button Send to Mhs seperti pada Gambar 11.

\section{B. Hasil Pengujian dan Analisis}

Berdasarkan hasil pengujian aplikasi ini oleh mahasiswa, didapat angka 94,1\% yang setuju bahwa dalam segi interface aplikasi dapat dikenali dengan mudah. Dalam segi kemudahan dalam melakukan registrasi dan Login 100\% mahasiswa yang menyetujui hal ini. Sedangkan untuk layanan pengoperasian, dan efektivitas, terdapat 94,1\% mahasiswa yang setuju bahwa aplikasi ini layak dalam segi fungsionalitas dan 5,9\% mahasiswa yang tidak setuju bahwa aplikasi ini memberikan efektivitas dalam kemudahan peminjaman laboratorium. Berdasarkan hasil pengujian aplikasi oleh sejumlah penanggung jawab yang terkait dalam alur atau proses peminjaman laboratorium, didapat kesimpulan bahwa aplikasi ini dapat digunakan untuk memberikan pelayanan yang lebih efektif dari segi pengajuan peminjaman laboratorium dan bukti peminjaman laboratorium yang ada dibanding dengan hanya menampilkan informasi peminjaman laboratorium berbasis Web saja. Selain itu, Sistem Informasi Peminjaman Laboratorium pada Cross-Platform dengan Metode Prototyping menyediakan informasi tentang apa saja yang diperlukan dalam melakukan peminjaman laboratorium lewat kolom formulir pengajuan peminjaman laboratorium yang harus diisi sesuai dengan ketentuan yang ada dan dapat digunakan secara fleksibel baik bagi pengguna $i O S$ ataupun Android.

\section{KESIMPULAN}

Berdasarkan penelitian yang telah dilaksanakan, didapatkan hasil dan kesimpulan bahwa Sistem Informasi
Peminjaman Laboratorium pada Cross-Platform dengan Metode Prototyping dapat dijalankan dengan baik dan semestinya. Aplikasi ini dapat digunakan sebagai salah satu fasilitas yang dapat mempermudah kinerja pengawasan terhadap peminjaman laboratorium melalui daftar peminjaman laboratorium, selain itu aplikasi ini menyediakan informasi tentang apa saja yang diperlukan dalam melakukan peminjaman laboratorium lewat kolom formulir pengajuan peminjaman laboratorium yang harus diisi sesuai dengan ketentuan yang ada. Kelebihan dari aplikasi ini adalah dapat diakses secara fleksibel baik bagi pengguna $i O S$ ataupun Android.

Fitur utama dari aplikasi ini adalah bukti peminjaman laboratorium dengan format .pdf yang disediakan oleh expo [10] dan tidak perlu dicetak. Selain aplikasi menyediakan komponen yang tidak difasilitasi oleh sistem informasi laboratorium lab.pcr.ac.id baik dari segi pengajuan, informasi log peminjaman peralatan dan bukti peminjaman. Berdasarkan hasil data yang diperoleh dengan menggunakan fitur kuisoner dan pengujian secara langsung, terdapat sekitar 94.1\% mahasiswa setuju bahwa aplikasi ini dapat menjadi jalan yang efektif dan efisien dalam peminjaman laboratorium dibandingkan dengan sistem sebelumnya lab.pcr.ac.id.

\section{UCAPAN TERIMA KASIH}

Penulis mengucapkan terima kasih kepada pihak yang telah banyak memberikan bantuan dan dukungan yang tiada terhingga baik secara langsung maupun tidak langsung kepada Tuhan YME, Politeknik Caltex Riau dan Politeknik Negeri Batam.

\section{DAFTAR PUSTAKA}

[1] M. Thuné and A. Eckerdal, 'Analysis of Students' learning of computer programming in a computer laboratory context', Eur. J. Eng. Educ., vol. 44, no. 5, pp. 769-786, 2019.

[2] F. Nuraeni, 'Sistem Informasi Inventori Barang Laboratorium Komputer Berbasis Android di STMIK Tasikmalaya', Prosiding SNIF September 2014

[3] H. M. Mahi, 'Pembangunan Aplikasi Pemantauan Kegiatan Siswa Berbasis Mobile Menggunakan Framework React Native (Studi Kasus: Pemantauan Kegiatan Siswa di MI Cahaya Chimahi)' 2019.

[4] S. Tilkov, S. Vinoski, 'Node.js: Using JavaScript to Build HighPerformance Network Programs' IEEE Internet Computing, 2010.

[5] M. Kuitunen, 'Cross-Platform Mobile Application Development with React Native' 2019 http://urn.fi/URN:NBN:fi:tty-201902111234.

[6] E. Masiello, J. Friedmann, 'Mastering React Native'. Packt Publishing Ltd 2017.

[7] R. Conway, M. Koch, and L. Salinas, "Prototyping Software Development Cycle", secs, vol. 4, no. 1, Apr. 2019.

[8] E. Torlak 'UML Sequence Diagram'. Course Material. Available; https://courses.cs.washington.edu/courses/cse403/15sp/lectures/L10. pdf

[9] Expo Push Notifications. Available: https://docs.expo.io/versions/latest/guides/push-notifications/

[10] D. E. Kurniawan, 'Push Notification System Pada Prototype Kendali Listrik Rumah', CESS (Journal Comput. Eng. Sci. Syst., vol. 2, no. 2, pp. 89-92, 2017.

[11] React Native PDF npmjs. Retrieved from: https://www.npmjs.com/package/react-native-pdf 